\title{
ITP Filtrate Benzene Removal Alternatives
}

by

L. O. Dworjanyn

Westinghouse Savannah River Company

Savannah River Site

Aiken, South Carolina 29808

\section{MASTEPYY}

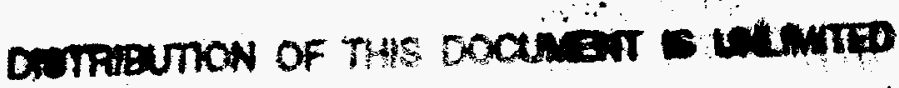

DOE Contract No. DE-AC09-89SR18035

This paper was prepared in connection with work done under the above contract number with the U.S. Department of Energy. By acceptance of this paper, the publisher and/or recipient acknowledges the U. S. Government's right to retain a nonexclusive, royalty-free license in and to any copyright covering this paper, along with the right to reproduce and to authorize others to reproduce all or part of the copyrighted paper. 


\section{DISCLAIMER}

This report was prepared as an account of work sponsored by an agency of the United States Government. Neither the United States Government nor any agency thereof, nor any of their employees, makes any warranty, express or implied, or assumes any legal liability or responsibility for the accuracy, completeness, or usefulness of any information, apparatus, product, or process disclosed, or represents that its use would not infringe privately owned rights. Reference herein to any specific commercial product, process, or service by trade name, trademark, manufacturer, or otherwise does not necessarily constitute or imply its endorsement, recommendation, or favoring by the United States Government or any agency thereof. The views and opinions of authors expressed herein do not necessarily state or reflect those of the United States Government or any agency thereof.

This report has been reproduced directly from the best available copy.

Available to DOE and DOE contractors from the Office of Scientific and Technical Information, P.O. Box 62, Oak Ridge, TN 37831; prices available from (615) 576-8401.

Available to the public from the National Technical Information Service, U.S. Department of Commerce, 5285 Port Royal Road, Springfield, VA 22161. 


\section{DISCLAIMER}

Portions of this document may be illegible in electronic image products. Images are produced from the best available original document. 
Westinghouse Savannah River Company
Savannah. RIver Technology Center
WSRC-RPP $-93-767$

Keywords: Benzene stripping, Gas Sparging, GOOD OLE In-Tank Process, HAJK Henry's Constant,

Retention Period: Permanent

CC: B.G. Croleyn 241-120H

J.R Brooke, 241-120H

W.B. Van Pelt, 241-152H

T.P. Gaughan, 241-152H

G.A. Taylor, 241-152H

G.K. Georgeton, 703-H

D.B. Burns, 676-T

J.E. McGlynn, 773-A

E.W. Holtzscheiter, 773-A

L.E. Landon, 704-T

M.D. Boersma, 704-T

M.A. Baich, 704-T

W.E. Stevens, 773-A

S.D. Eink, 773-A

D.D. Walker, 773-A

SRTC Records (4)

May 21, 1993

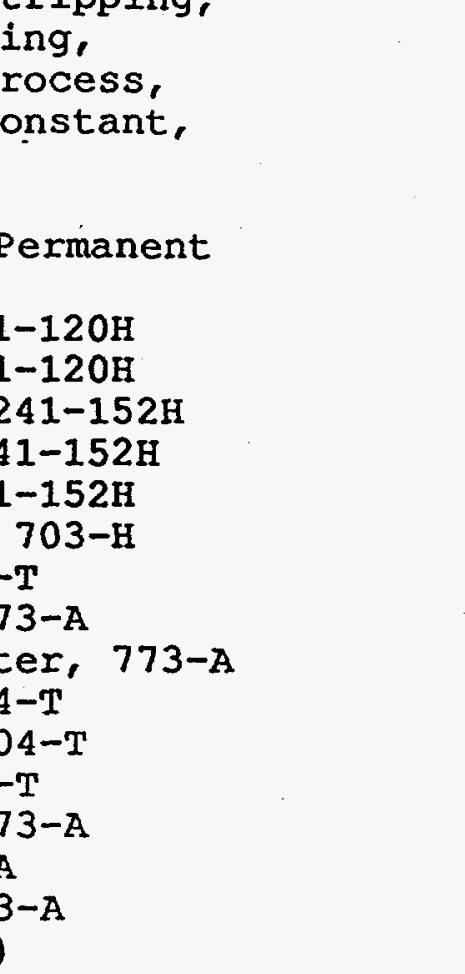

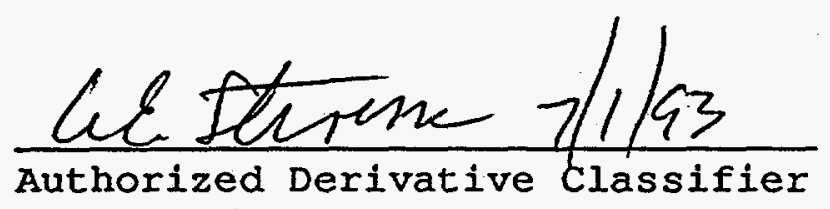

TO:

W.L. Tamosaitis, 773-A

FROM: $\quad$ L.O. Dworjanyn, 779-2A

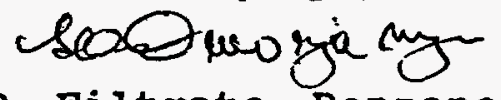
ITP Filtrate Benzene
Bemeral Alternatives
CC:

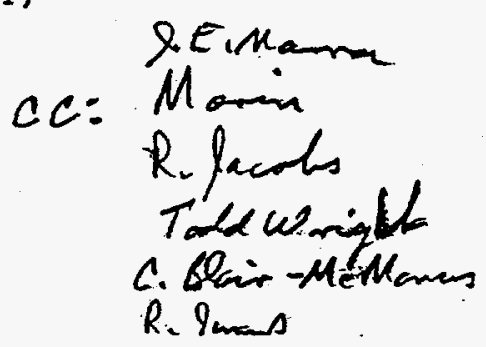

(U)

\section{SUMMARY}

Existing ITP filtrate hold tanks maky provide sufficient capacity and residence time to strip dissolved benzene from the incoming filtrate using nitrogen sparging in the bottom of the hold tanks. This is based on equilibrium supported by Late Wash test data using aged washed slurry. Theoretical considerations indicate that benzene stripping will be more difficult from the ITP unwashed high salt filtrates due to reduced mass transfer. Therefore experinerita sparging data is needed to quantify the theoretical effects. Eormiting limits which dictate allowable sparging rate whinkatsonhave to be "established. Sparging in the 
hold tanks will require installation of sintered metal spargers, and possibly stirrers and foam monitoring/disengagement equipment.

The most critical sparging needs are at thej start of the precipitation/concentration cycle, when the filtrate flux rate is the highest, and at the end of the wash cycle where Henry's equilibrium constant falls off, requiring more gas to sparge the dissolved benzene.

With adequate recycle (for proper pating distributionl) or sparging in the hold tanks, the 30 inch column could be used for the complete ITP process. A coxprer packing would reduce back pressure while enabling benzene stripping. The Late Wash tests indicate adequate benzene stripping even at reduced gas flow. This will require experimental verification under ITP conditions. Using the $30 \mathrm{in}$. column vs 18 in. during the wash cycle will enhance stripping without need for additional sparging provided the minimum flow requirements are met.

\section{RECOMMENDATIONS}

- Provide experimental datạ to validate sparging in hold tanks under ITP conditions.

- Use only the larger $30 \mathrm{in.} \mathrm{stripper} \mathrm{column} \mathrm{for} \mathrm{the} \mathrm{whole} \mathrm{ITP}$ cycle.

- Evaluate other (coyxser) packings in the 30 inch column.

\section{BACKGROUND}

Unexpectedly high pressure drops were observed in an ITP benzene stripping column during cold chemicals testing of cross-flow filters. The $30 \mathrm{in}$. column pressure drop reached the 40 in. water operating limit at half the design liquid flow and one quarter design nitrogen stripping gas flow. Subsequent vendor tests using simulated filtrates showed that the pressure drop is due to foaming and can be significantly reduced with tributyl phosphate. The dissolved benzene also had a small anti-foaming effect. Also different batches of simulant showed different levels of foaming and resulted in differing pressure drops.

The pressure drop was not predicted during the initial stripper column design and real tank waste may behave differently, even in the presence of tributyl phosphate. Benzene removal from ITP filtrate is essential to meet Class A saltstone quality. Existing ITP equipment has been examined to provide back-up benzene removal alternatives.

\section{DISCUSSION}

Mark Baiohe Late Wash spargihg tests'(Ref 1) show that benzene is removed to near equilibriumlas determined by Henry's Law Constant. The stripping kinetics remain very fast down to about 2 ppm goat benzene concentration (Fig 2). The tests were conducted on washed yaged' (irratiated) slurry in a well stirred 30 gal. tank 
(1/200 th scale STRAT) using sparge rates of 0.3 to $0.6 \mathrm{SCFM} / \mathrm{ft}^{2}$. The sparge rate determines the benzene stripping rate and is

(ultimately limited by foaming. The vendor recommends $0.62 \mathrm{SCFM} / \mathrm{ft}^{2}$ of sparge surface at 0.5 micron porosity. The Baich data provides only a product of Henry's Constant and sparging efficiency since the actual Henry's Constant for Late Wash irradiated solution is not known. For ITP stripping we assumed a 50 z sparging efficiency. This may improve inside taller tanks as the contact time increases, or decrease as mixing becomes less effectíve in larger tanks. Based on Gus Georgeton's calculations (Ref 5), the mass transfer coefficient will decrease with increasing salt concentration and the assumed $50^{\circ}$ efficiency may decreaserduring: the concentration cycle. This will require experimental determination under selected ITP conditions.

Benzene stripping for batch operation can be represented by ( $\operatorname{Ref} 1)$ :

$$
C(t)=C_{0} \exp (-\operatorname{sHEt} / \mathrm{V}\rangle
$$

where $\quad C(t)$ is benzene concentration at time $t$ (min) $C_{0}$ is benzene concentration at the start

$S$ is sparge gas flow (SCFM)

$\mathrm{H}$ is Henry's Constant

$E$ is the stripping efficiency

$\mathrm{V}$ is the tank liquid working volume ( $\left.\mathrm{ft}^{3}\right)$

Henry's Constants for "average" salt solution have been provided by Walker (Ref 2) as a function of temperature and [ $\left.\mathrm{Na}^{+}\right]$ concentration. The values for "average" salt can be adjusted for high and low $\mathrm{OH}^{-}$as shown in Table 1 to better represent the ITP precipitation/ concentration/ washing cycle (Ref 3 ).

The calculated time for sparging 10,000 gal of high oH filtrate during the concentration cycle is shown in Figure 3 . The sparging time to reduce benzene concentration from $120 \mathrm{ppm}$ to $2.5 \mathrm{ppm}$ falls off rapidly as the salt concentration increases, assuming. the efficiency remains at $50 \%$. However, we would expect the efficiency to decrease with increased salt concentration and experimental data must be provided to validate the assumptions.

During the wash cycle benzene concentration will be higher, and the stripping time will increase as the salt is washed out from $5 \mathrm{M}$ to say IM sodium, Figure 4 . At $500 \mathrm{ppm}$ starting concentration it may take 10 hrs. to strip the benzene to $2.5 \mathrm{ppm}$.

The estimated time to fill the hold tanks and to strip the benzene over the whole ITP cycle is shown in Figure 1, based on ITP cold chemicals filtrate flux rate Figure 5 (Ref 4 ). During the concentration cycle benzene stripping will be relatively constant and quick since the highly concentrated salt solution holds little benzene. As the solids are concentrated the filter flux rate will fall off allowing more time for stripping. 
During the wash cycle the filter flux will remain relatively constant and low, however, the stripping time will increase as the salt is washed out and Henry's constant decreases by a factor of 10. The flowrates, benzene concentration, tand Henry's constant used are highlighted in Table 1.

\section{REFERENCES}

(1) M.A. Baich, "Qualification of Data $1 / 200$ th Scale STRAT Late Wash Permeate Sparging", WSRC-RP-93-229, 1/20/93.

(2) D.D. Walker to G.T. Wright, "Vapor Pressure of Benzene, Methanol and Isoprapanol over Salt Solutions", DPST-88-661, $3 / 28 / 89$.

(3) D.D. Walker, "Material Balance for the ITP Process with Late Washing", SRT-LWP-92-074, 7/14/92.

(4) L.O. Dworjanyn to W.I. Tamosaitis, "ITP Eilter Particulate Decontamination", WSRC-RP-93-768, 5/21/93.

(5) G.K. Georgeton, "Development and Application of a Mathematical Model for the Benzene Stripping Columns in the ITP Process", WSRC-RP-89-1442, 12/28/89. 
C.APPNTPISTRIP.WQI

PrecipitationVConcentration, $\mathrm{High} \mathrm{OH}$

$\begin{array}{rrr}\text { Nat } & \begin{array}{r}25 \mathrm{deg} \\ \text { Avg }\end{array} & \mathrm{HiOH} \\ & & \\ 0 & 0.23 & 0.23 \\ 1 & 0.35 & 0.37 \\ 2 & 0.56 & 0.63 \\ 3 & 0.87 & 1.04 \\ 4 & 1.35 & 1.71 \\ 5 & 2.13 & 2.84 \\ 6 & 3.33 & 4.66\end{array}$

Precipitate Washing, High OH

$\begin{array}{rrr}\text { Nat } & \begin{array}{r}25 \text { deg } \\ \text { Avg }\end{array} & \text { HiOH } \\ & & \\ 0 & 0.23 & 0.23 \\ 1 & 0.35 & 0.37 \\ 2 & 0.56 & 0.63 \\ 3 & 0.87 & 1.04 \\ 4 & 1.35 & 1.71 \\ 5 & 2.13 & 2.84 \\ 6 & 3.33 & 4.66\end{array}$

Strip

10.7

6.6

3.9

2.4

1.4

0.9

0.5
120 Avh $\begin{array}{rr}\text { Fill } \\ \text { hr. } & 115 \\ & \text { hr }\end{array}$

0.33

0.5

0.78

1.22

1.91

2.98

4.65

$\begin{array}{lll}0.33 & 7.5 & 1.4 \\ 0.53 & 4.6 & 1.4 \\ 0.88 & 2.8 & 1.4 \\ 1.46 & 1.7 & 1.4 \\ 2.42 & 1.0 & 1.4 \\ 3.97 & 0.6 & 1.4 \\ 6.51 & 0.4 & 1.4\end{array}$

1.4
1.4
1.4
1.4
1.4
1.4
1.4
Strip

hir

14.7

9.0

5.3

3.2

2.0

1.2

0.7
500

$35 \operatorname{deg} \mathrm{C}$

Avh $\mathrm{HiOH}$

0.33

0.5

0.78

1.22

1.91

2.98 .

4.65

0.44

0.67

1.03

1.58

2.43

3.73

5.72

$\begin{array}{rrr}0.33 & 10.2 & 11.9 \\ 0.53 & 6.3 & 11.9 \\ 0.88 & 3.8 & ; 11.9 \\ 1.46 & 2.3 & 11.9 \\ 2.42 & 1.4 & 11.9 \\ 3.97 & 0.8 & 11.9 \\ 6.51 & 0.5 & 11.9\end{array}$

14
$\mathrm{hr}$

$45 \mathrm{deg} \mathrm{C}$

$\mathrm{HiOH} \mathrm{hr}$

$\begin{array}{ll}0.44 & 5.6 \\ 0.71 & 3.4 \\ 1.17 & 2.1 \\ 1.90 & 1.3 \\ 3.08 & 0.8 \\ 4.97 & 0.5 \\ 8.01 & 0.3\end{array}$

$5 \operatorname{deg} C$

hr

5.6

2.1

1.3

0.5

0.3

Operation:

$X$-Axis Plot

Concentration

Solids, wt\%

2

4

6

$\begin{array}{ll}8 & 10 \\ 8 & 10\end{array}$

10

Washing

$\begin{array}{lll}0.44 & 0.44 & 7.7\end{array}$

0.67

0.71

4.7

- 1.58

1.17 .

2.9.

Natel comoni

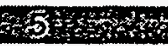

[OH] Level

$\mathrm{Hi} \quad \mathrm{Hi}$

$\mathrm{Hi} \quad \mathrm{Hi}$

2.43

1.90

1.8

3.08

1.1

3.73

4.97

0.7

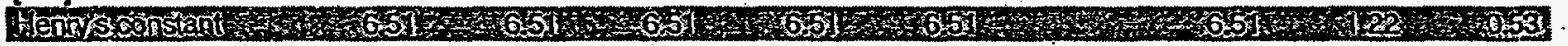

\begin{tabular}{|c|c|c|c|c|c|c|c|}
\hline $\begin{array}{l}\text { Walker Cycle, gpm } \\
\text { ITP Test Flow, gpin }\end{array}$ & $\begin{array}{l}115 \\
104\end{array}$ & $\begin{array}{r}115 \\
59\end{array}$ & $\begin{array}{r}115 \\
39\end{array}$ & $\begin{array}{r}115 \\
26\end{array}$ & $\begin{array}{l}50 \\
17\end{array}$ & $\begin{array}{l}14 \\
14\end{array}$ & $\begin{array}{l}14 \\
14\end{array}$ \\
\hline
\end{tabular}

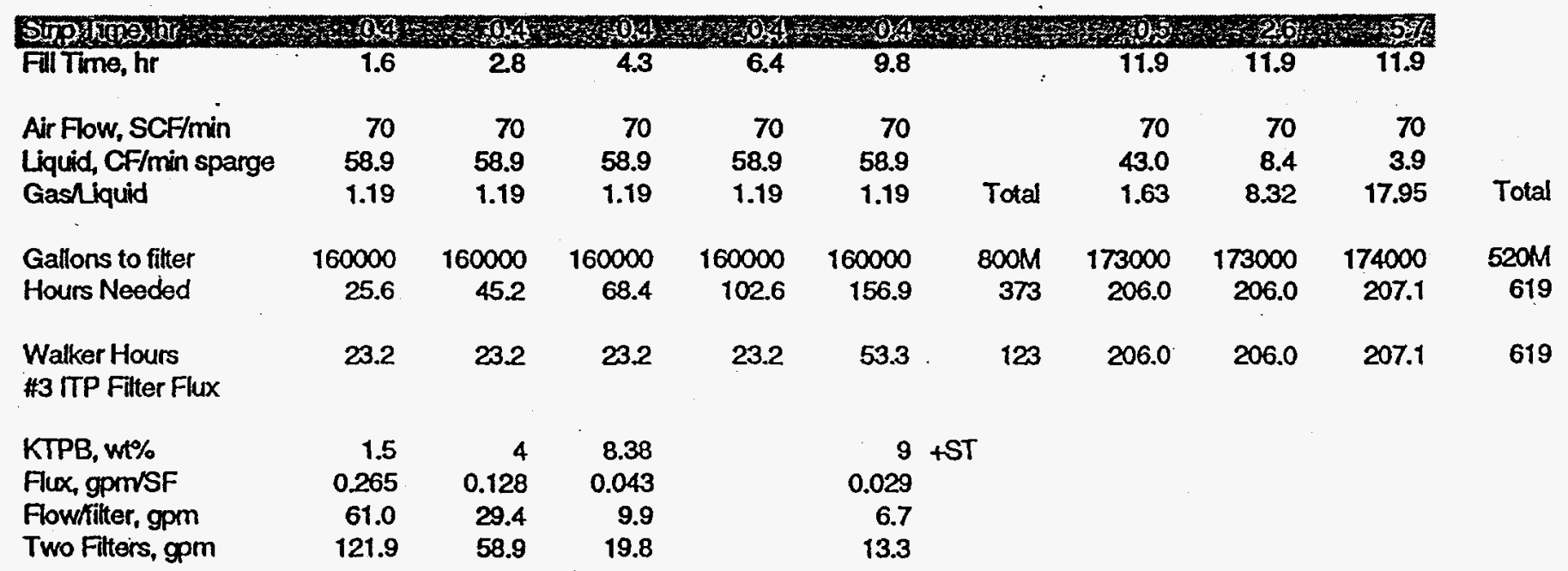




\section{ITP Cycle Sparging Time Time to Reduce Benzene to $2.5 \mathrm{ppm}$}

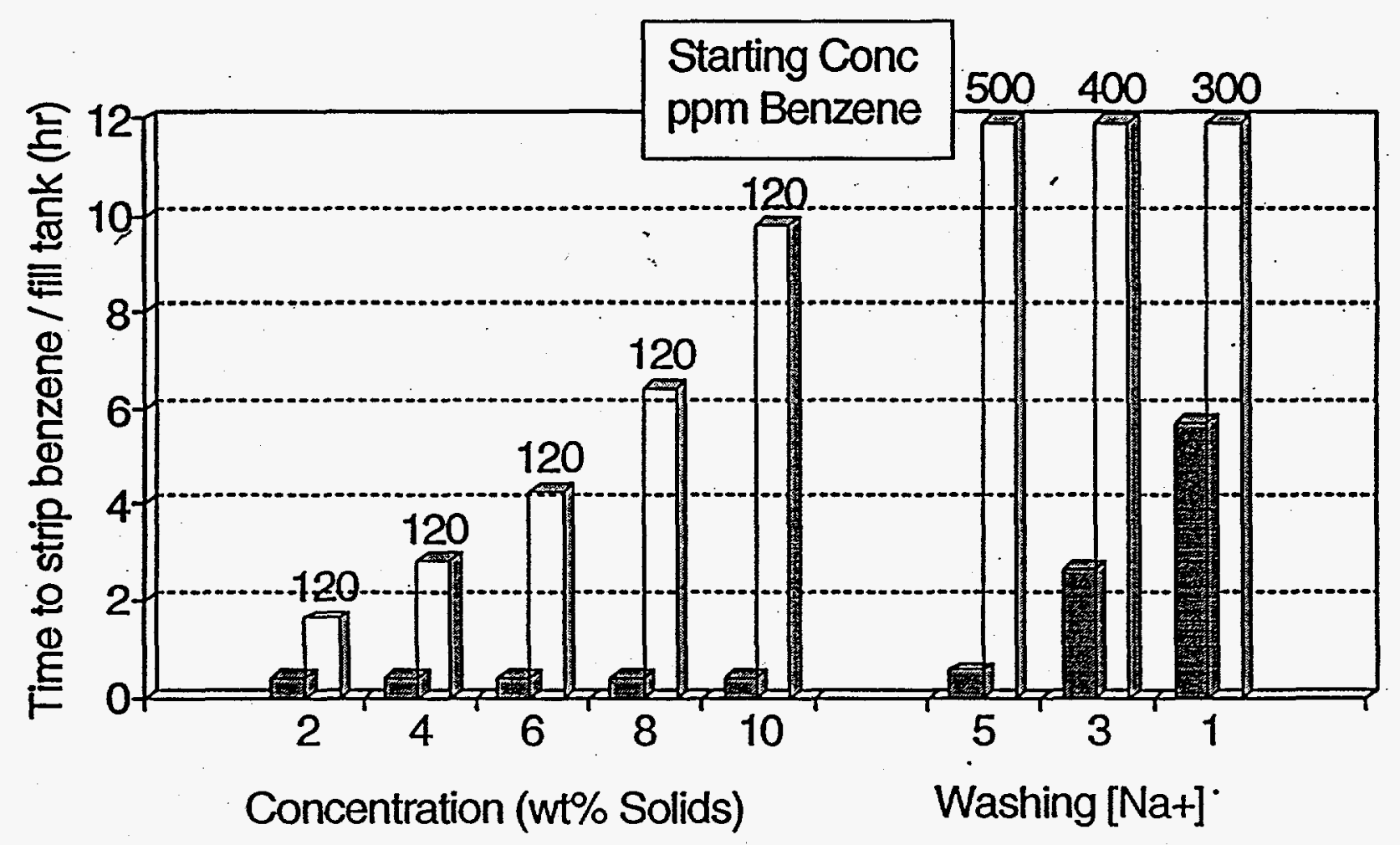

Sparging Time (hr) $\square$ Available Time (hr)

NOTE :

During CONCENTRATION filtrate flux rate decreases, increasing the available time for sparging. Assumed temperature $=35^{\circ} \mathrm{C}$
During PRECIPITATE WASHING salt concentration decreases, decreasing Henry's constant and increasing sparging time. 


\section{Late Wash Sparging Mark Baich, Test Run \#3}

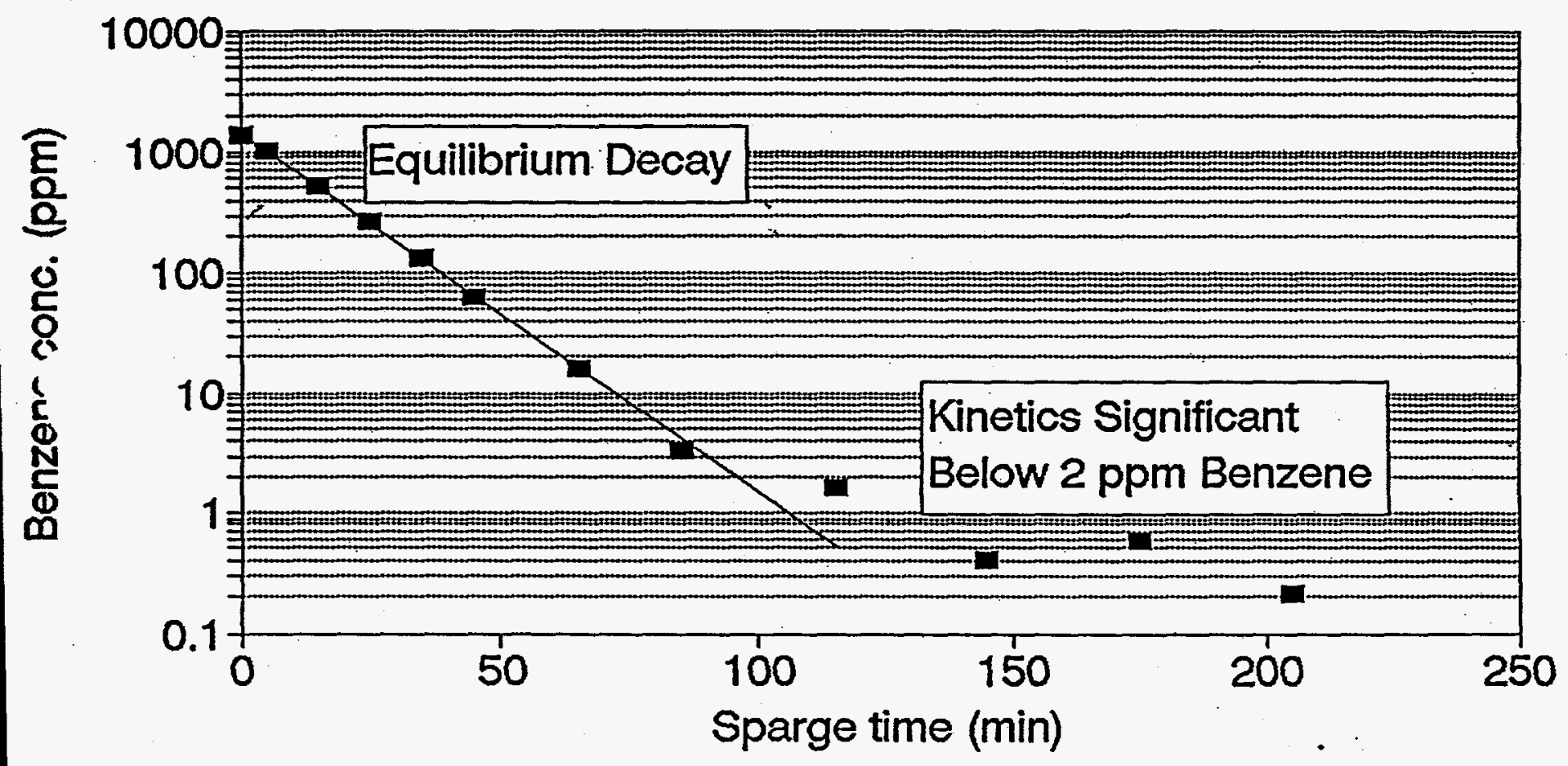

- Data - Theory Fit 


\section{Hold Tank Sparging $120 \mathrm{ppm}$ Benzene to $2.5 \mathrm{ppm}$}

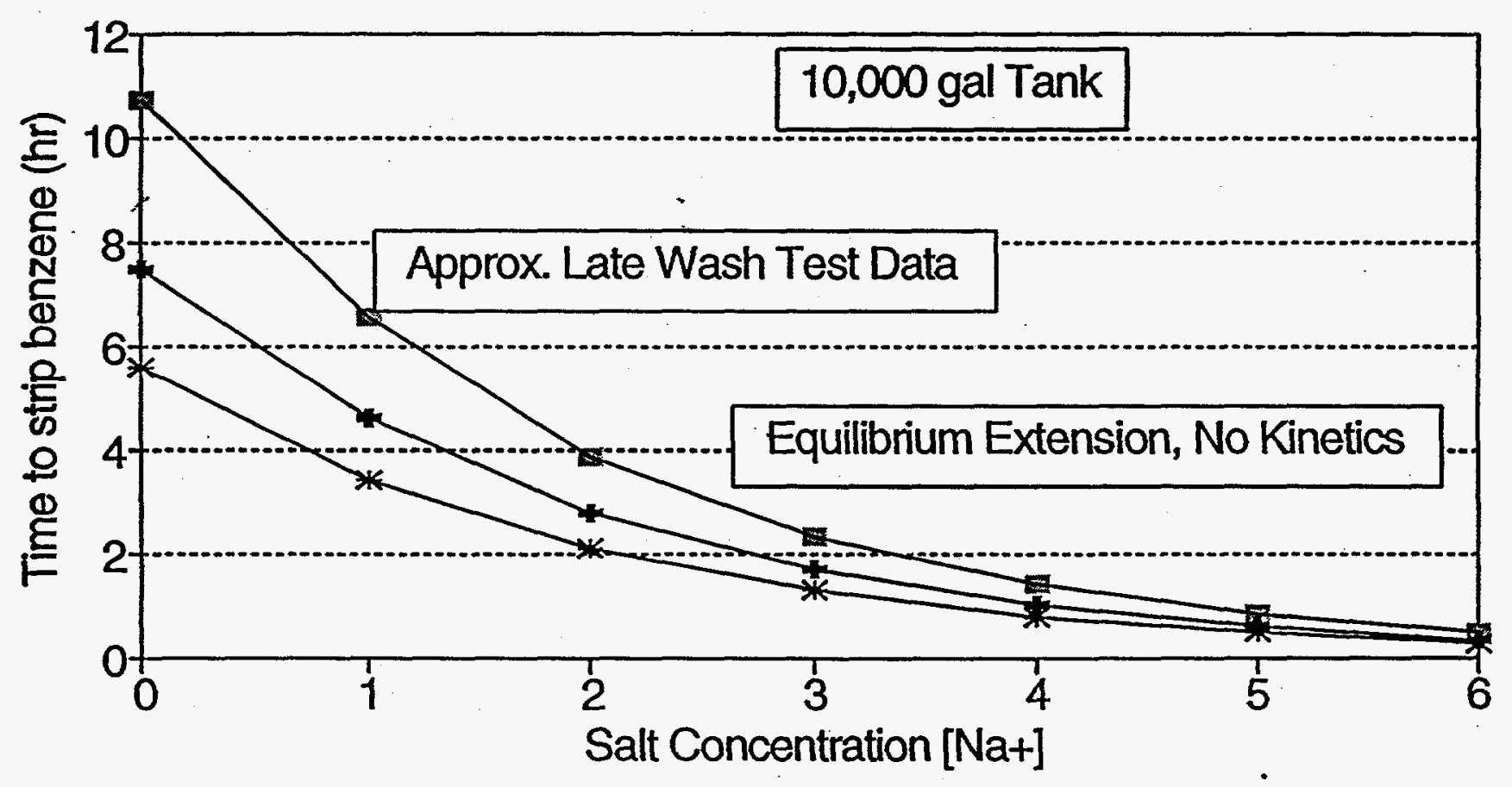

$-25 \operatorname{Deg} C *-35 \operatorname{Deg} C *-45 \operatorname{Deg} C$ 


\section{Hold Tank Sparging $500 \mathrm{ppm}$ Benzene to $2.5 \mathrm{ppm}$}

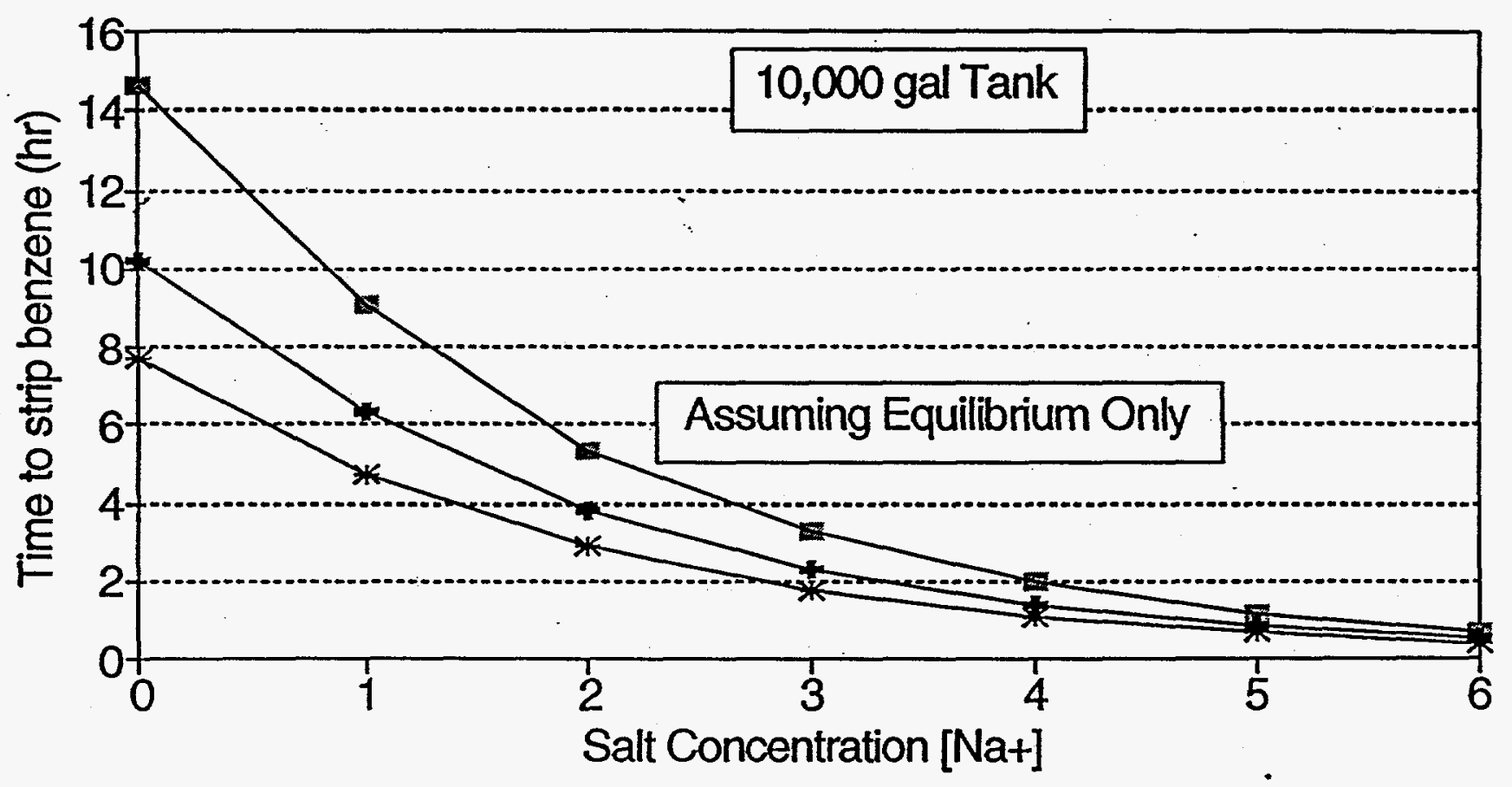

$-25 \operatorname{Deg} C \rightarrow-35 \operatorname{Deg} C \rightarrow-45 \operatorname{Deg} C$ 


\section{ITP Filtrate Flux Unit \#3 STRIP.WQ1 LOG_FIT}

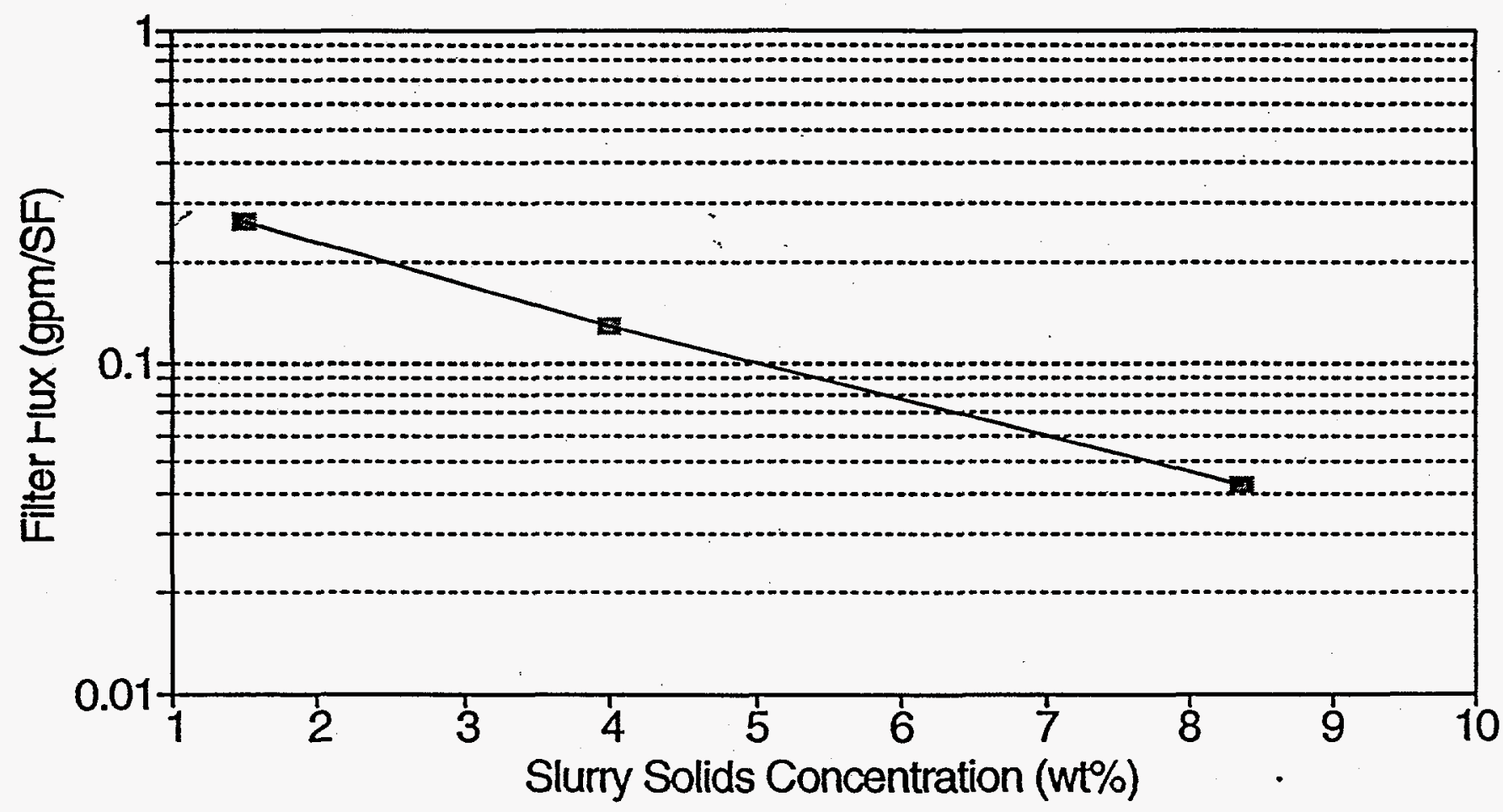

- ITP Data 